\title{
Mechanical Properties of Composite Mortars Using Flurogypsum and PVC Particles
}

\author{
Luisa Maria Flores-Vélez1, Hector Valle², Gabriel García², Roberto Torres², \\ Martha Lomelíi ${ }^{3}$ Octavio Domínguez ${ }^{3}$ \\ ${ }^{1}$ Facultad de Química-UASLP, Salvador, México \\ ${ }^{2}$ Mexichem Flúor, San Luis Potosí, México \\ ${ }^{3}$ Instituto de Metalurgia-UASLP, San Luis Potosí, México \\ Email: nanoquimica@yahoo.com
}

Received 16 January 2014; revised 17 February 2014; accepted 28 February 2014

Copyright (C) 2014 by authors and Scientific Research Publishing Inc.

This work is licensed under the Creative Commons Attribution International License (CC BY). http://creativecommons.org/licenses/by/4.0/

(c) (i) Open Access

\begin{abstract}
The present work describes the viability of a mortar binder based on two industrial by-products: poly(vinyl chloride) (PVC) particles from scrap and anhydrite $\left(\mathrm{CaSO}_{4}\right)$ from fluorgypsum. Mortar composites were made incorporating different amounts of PVC particles and cured at constant room temperature during various periods of time. From $\mathrm{X}$-ray diffraction, it was possible to follow the hydration process and to estimate the effect of the PVC particles on anhydrite transformation to gypsum $\left(\mathrm{CaSO}_{4} \cdot 2 \mathrm{H}_{2} \mathrm{O}\right)$. Compressive strength from uniaxial testing was measured from stressstrain curves carried out at room temperature. According to these results, the hydration rates of the composites depend on the concentration of PVC particles and there is an enhancement in their compressive strength as particle content increases, reaching values of $36 \mathrm{MPa}$ after 28 days.
\end{abstract}

\section{Keywords}

Compressive Strength; Recycled PVC; Hydraulic Binder; Alternative Building Materials; Gypsum-Composite

\section{Introduction}

Poly(vinyl chloride) PVC is one of the most commonly used thermoplastic materials in respect to the worldwide polymer consumption. At global level, demand for PVC exceeds 35 million tonnes per year, and it is rated second only after polyethylene as volume leader in the plastics industry [1]. Currently, PVC can be processed into a wide variety of short-life products, such as packaging materials used in food, cleansing materials, textile, beverage packaging bottles, and medical devices, and also long-life building material products such as pipes, window frames, cable insulation, floors coverings, roofing sheets, etc. [2]. In recent years, the question of the 
disposal of PVC waste has gained increasing importance in the public discussion, resulting from the rapid growth of the PVC wastes. Despite the advantages of recycling, unfortunately only a small part of PVC waste is now recycled in the word [3] [4].

Gypsum has been used as a construction material since ancient times. The modern building industry can utilize not only natural gypsum, as commonly done in the past, but also other forms of gypsum that appear as waste secondary raw material from various sources, such as phosphogypsum and fluorgypsum [5] [6], red gypsum [7] and flue-gas desulfurization gypsum [8]. The current application of gypsum in construction is relatively limited, despite the low price of raw material and the general recognition of recycled gypsum as an environmentalfriendly material. Besides, there is an increasing interest in alternative binders for sustainable building construction [9]. The most often use of gypsum in buildings is still in the form of interior plasters and plasterboards, however, the potential for gypsum applications could be much wider. Another prospective way is the development of lightweight gypsum which can be produced either as foamed-gypsum paste where the pore structure is formed by chemical additives [10] or using light aggregates of polyamides [11], rubber [12] polystyrene and polypropylene fibers [13]. Besides, the preparation of gypsum-based materials for thermal isolation and latent heat storage is a major research goal for this material [14].

Industrial activity creates a huge quantity of by-products as fluorgypsum, one kind of anhydrite $\left(\mathrm{CaSO}_{4}\right)$ by-product from the production of hydrofluoric acid. Its annually discharged magnitude is as high as 100,000 tons for a middle-scale plant. Though some of the fluorgypsum is used in the cement industry as a set regulator of Portland cement, its main part is still placed in disposal areas. There are reports concerning fluorgypsum mortars made by mixing other by-products as fly-ash [15], Portland cement [16], slag [5] and silica fume [17], but to the best of the authors' knowledge, no previous research has been conducted on the effects of using PVC particles on fluorgypsum.

The present work investigates the effects of incorporating particles from recycled PVC scrap as a partial reinforcement for anhydrite on the properties of these composite mortars. This preliminary study emphasizes the effect induced by PVC particles in gypsum hydration and the enhancement in compressive strength as particle content reaches an optimal value, opening the prospective of lightweight gypsum composite. Hence, this work presents the preliminary results about the influence of PVC particles on anhydrite and their combined properties for alternative composite binders.

\section{Experimental Procedure}

The materials used were domestic fluorgypsum (Mexichem Fluor, Matamoros, México), PVC particles (scrap obtained from milling of PVC pipes), $\mathrm{K}_{2} \mathrm{SO}_{4}$ (Fluka 98\%) as additive to promote anhydrite hydration and industrial grade slaked lime $\mathrm{Ca}(\mathrm{OH})_{2}$ as neutralizing agent.

\subsection{Instrumental Techniques}

X-ray diffraction (XRD) experiments were performed employing a diffractometer using $\mathrm{Cu} \mathrm{K}_{\alpha}(\lambda=0.154056$ $\mathrm{nm}$ ) radiation and nickel monochromator over the range $2 \theta$ from $10^{\circ}$ to $60^{\circ}$, with a scanning speed of $0.01^{\circ} / \mathrm{min}$ and an integration time of 2 seconds. Compressive strength from uniaxial testing was measured from stressstrain curves carried out at room temperature using a universal testing machine with capacity of $20 \mathrm{kN}$ under displacement control and a crosshead speed of $0.50 \mathrm{~mm} / \mathrm{min}$. Micrographs of the composites were taken using a scanning electron microscope (SEM) under an accelerating voltage of $20 \mathrm{kV}$ and chemical microanalysis was performed using an energy dispersive spectrometer (EDS) attached to the SEM. To assess the particle size distribution of the granular materials, SEM and sieve analysis were carried out using a mechanical shaker with a column of wire mesh screens.

\subsection{Materials Characterization and Composites Preparation}

All raw materials were dried and milled before mixing to avoid particle agglomeration. Fluorgypsum and slaked lime were grinded using a ball mill, meanwhile PVC particles were obtained by crushing pipes and then powdered using a pulverizer. Afterwards, samples were prepared by blending the proper amounts of each powder. Chemical analysis using atomic absorption spectrometry together with phase identification by X-ray diffraction were employed to obtained the chemical composition shown in Table 1 for the inorganic raw materials.

The results of particle analysis of the raw materials and their corresponding particle size distribution are 
shown in Figure 1. From these results it is found that PVC powder is conformed of coarse particles, having a mean particle diameter of $235 \mu \mathrm{m}$, whereas in the case of fluorgypsum, the mean particle size is quite small, approximately of $1.85 \mu \mathrm{m}$. SEM micrographs obtained from the powdered samples are presented in Figure 2, showing particle morphology for each case and the mean particle size.

XRD analysis was carried out in all raw materials to discern the mineralogical phases. Figure 3 shows the XRD patterns, indicating that fluorgypsum was conformed basically of anhydrite $\left(\mathrm{CaSO}_{4}\right)$ with a minor amount of fluorspar $\left(\mathrm{CaF}_{2}\right)$. PVC particles showed the presence of $\mathrm{CaCO}_{3}$ usually added as a filler and broad peaks associated to the poly(vinyl chloride) non-crystalline structure.

Because fluorgypsum is generated from the reaction between sulfuric acid $\left(\mathrm{H}_{2} \mathrm{SO}_{4}\right)$ and calcium fluoride $\left(\mathrm{CaF}_{2}\right)$ to obtain hydrofluoric acid $(\mathrm{HF})$, there is always a small amount of sulfuric acid $\left(\mathrm{H}_{2} \mathrm{SO}_{4}\right)$ remaining adsorbed at the surface of the $\mathrm{CaSO}_{4}$ particles, therefore a neutralizing treatment is required for the safe reprocessing of this product. Figure 4 represents the relationship between the $\mathrm{pH}$ of fluorgypsum slurry and the slake lime added. From the neutralization curve, it was observed that the as received fluorgypsum leads to a $\mathrm{pH}$ of 3 , nevertheless, a neutral $\mathrm{pH}$ of 7 is easily achieved when $0.26 \mathrm{wt} \%$ of $\mathrm{Ca}(\mathrm{OH})_{2}$ was added.

Table 1. Chemical composition of raw materials.

\begin{tabular}{ccc}
\hline wt\% & Fluorgypsum & Slaked lime \\
$\mathrm{SiO}_{2}$ & 0.53 & 3.50 \\
$\mathrm{Al}_{2} \mathrm{O}_{3}$ & 0.06 & - \\
$\mathrm{CaO}$ & 40.03 & 89.20 \\
$\mathrm{Na}_{2} \mathrm{O}$ & 0.04 & 0.62 \\
$\mathrm{MgO}$ & 0.09 & 2.13 \\
$\mathrm{Al}(\mathrm{OH})_{3}$ & - & 3.12 \\
$\mathrm{Fe}_{2} \mathrm{O}_{3}$ & 0.16 & 0.83 \\
$\mathrm{~K}_{2} \mathrm{O}$ & 0.03 & 0.60 \\
$\mathrm{CaF}_{2}$ & 1.45 & - \\
$\mathrm{SO}_{3}$ & 57.61 & - \\
\hline
\end{tabular}

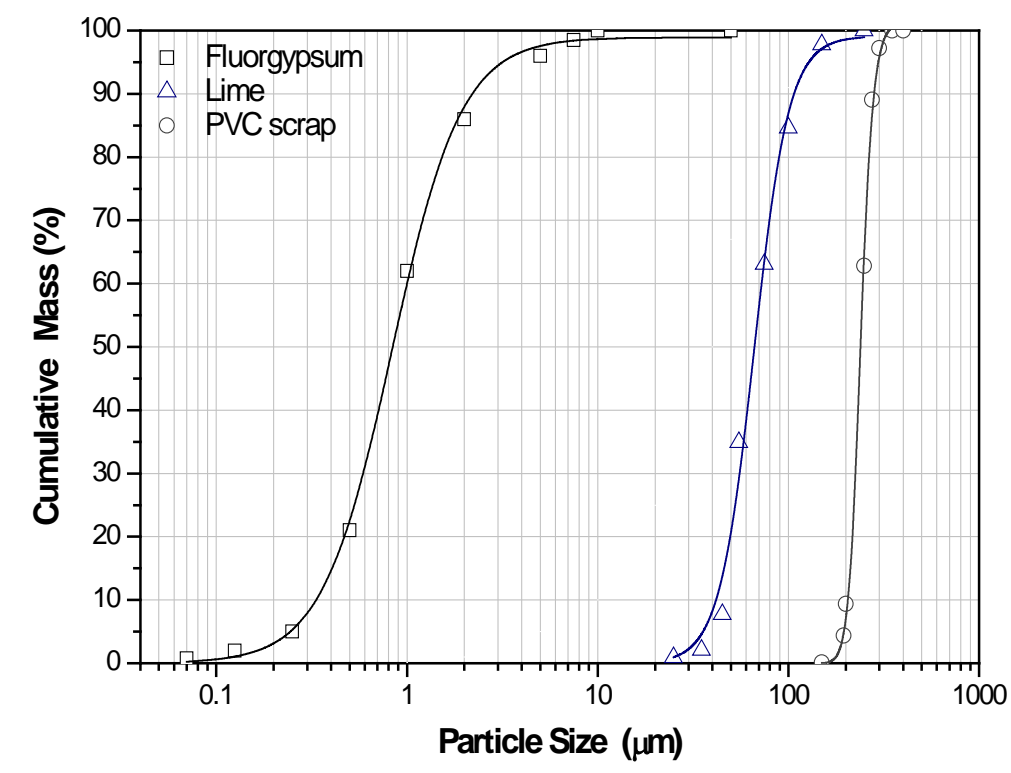

Figure 1. Particle size distribution curves of the powdered raw materials. The mean particle sizes were: fluorgypsum $1.85 \mu \mathrm{m}$, slaked lime $75 \mu \mathrm{m}$ and PVC particles $235 \mu \mathrm{m}$. 


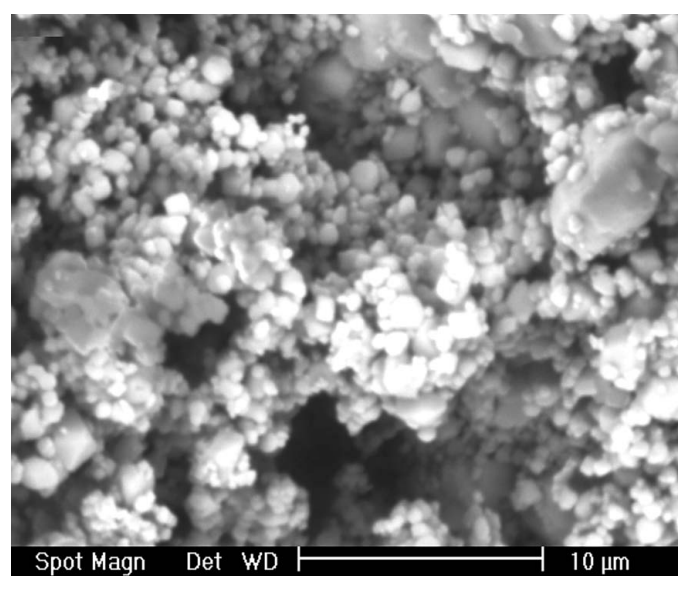

(a)

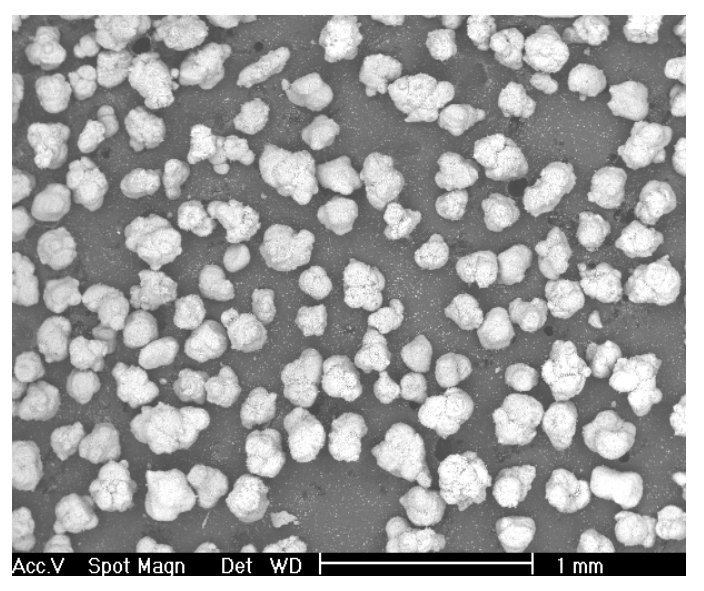

(b)

Figure 2. Scanning electron photographs of: fluorgypsum powder (a) and PVC particles (b).

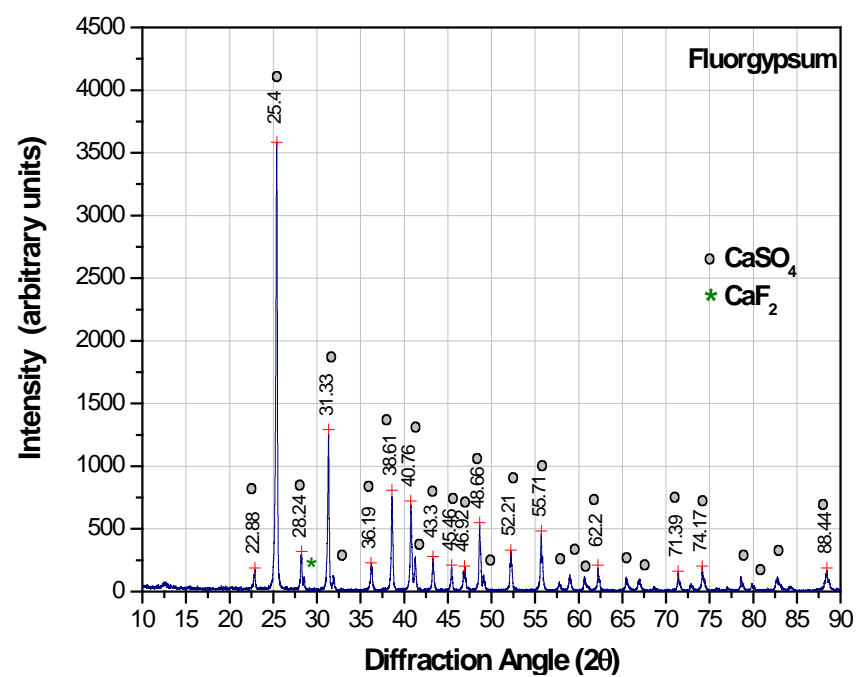

(a)

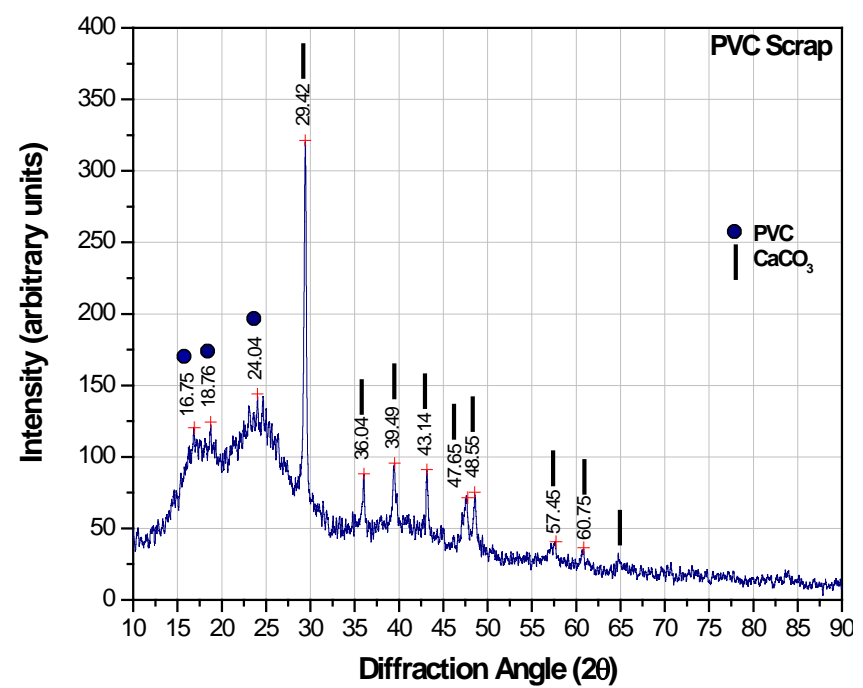

(b)

Figure 3. X-ray diffraction patterns of raw materials: (a) Fluorgypsum; (b) PVC particles. 


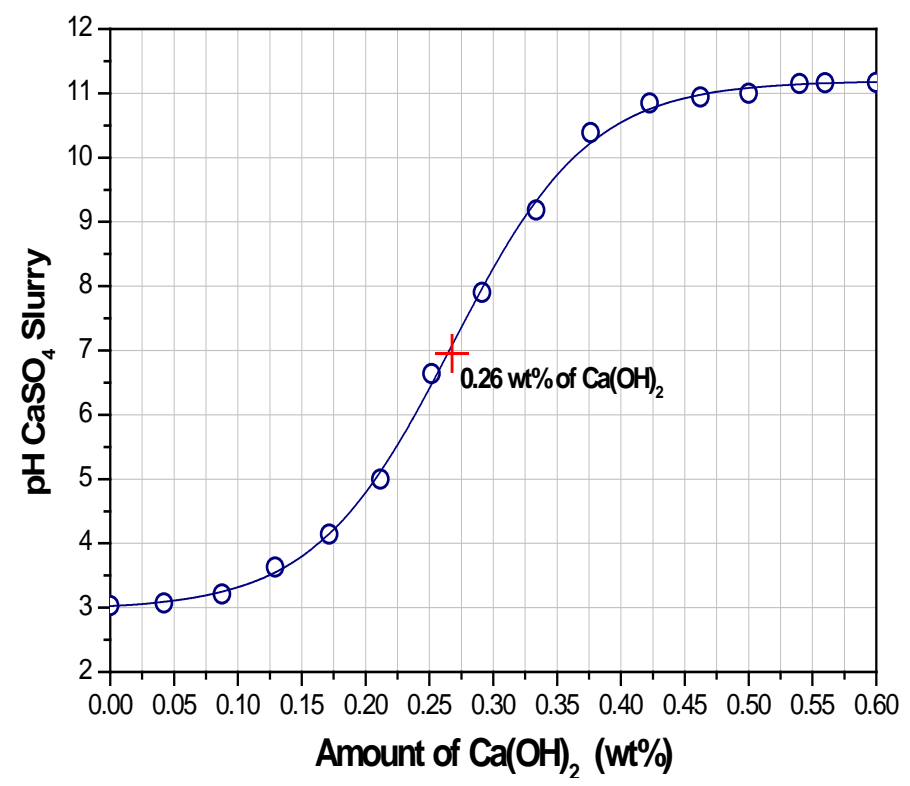

Figure 4. Variation of the $\mathrm{pH}$ versus the amount of $\mathrm{Ca}(\mathrm{OH})_{2}$ added to a slurry made of $50 \mathrm{~g}$ fluorgypsum and $17.5 \mathrm{~g} \mathrm{H}_{2} \mathrm{O}$ (water/fluorgypsum $=0.35$ ) at room temperature.

When water is added to anhydrite $\left(\mathrm{CaSO}_{4}\right)$, the hydration reaction must take place leading to gypsum $\left(\mathrm{CaSO}_{4} \cdot 2 \mathrm{H}_{2} \mathrm{O}\right)$ according to reaction [18]:

$$
\mathrm{CaSO}_{4}(\mathrm{~s})+2 \mathrm{H}_{2} \mathrm{O}(\mathrm{l}) \rightarrow \mathrm{CaSO}_{4} \cdot 2 \mathrm{H}_{2} \mathrm{O}(\mathrm{s})
$$

Unfortunately this process occurs very slowly leading to a solid with low strength development. However, when certain activators are added to the anhydrite, the hydration and strength are enhanced considerably.

From a large number of chemical activators, mainly metal sulfates, probably the most effective activator is potassium sulfate $\mathrm{K}_{2} \mathrm{SO}_{4}$ [19]-[21]. Figure 5 shows the evolution of the compressive strength of fluorgypsum once neutralized with $0.30 \mathrm{wt} \% \mathrm{Ca}(\mathrm{OH})_{2}$ and catalyzed with different concentrations of $\mathrm{K}_{2} \mathrm{SO}_{4}$. In all samples, the same 0.35 water/fluorgypsum ratio was kept constant and curing was carried out at a temperature of $25^{\circ} \mathrm{C}$. It was observed that formulations with $\mathrm{K}_{2} \mathrm{SO}_{4}$ gain strength quite rapidly, producing a compressive strength of over $10 \mathrm{MPa}$ after several days, where samples without activator fail to display any appreciable strength as indicated in Figure 5. From these results, therefore all composites were prepared using a water/fluorgypsum ratio of $0.35 \mathrm{wt} \%$ and $1.5 \mathrm{wt} \%$ of $\mathrm{K}_{2} \mathrm{SO}_{4}$.

Uniaxial compressive strength testing of the fluorgypsum-PVC composites after 3, 7, 15 and 28 days was performed on cylindrical samples with height and diameter of 4 and $2 \mathrm{~cm}$ respectively.

\section{Results and Discussion}

The hydration effect induced by PVC particles on the evolution of reaction (1) was examined from the XRD patterns of the composites at different times, indicating that the main crystalline compounds found in the cured composites were $\mathrm{CaSO}_{4}$ (anhydrite) and $\mathrm{CaSO}_{4} \cdot 2 \mathrm{H}_{2} \mathrm{O}$ (gypsum) and no evidence was detected of $\mathrm{CaSO}_{4} \cdot 1 / 2 \mathrm{H}_{2} \mathrm{O}$ (bassanite) after 3 days.

Figure 6 corresponds to XRD patterns obtained after curing composites for 3 days. The main peak of $\mathrm{CaSO}_{4}$ (anhydrite) corresponding to the (100) crystallographic planes appears at a $2 \theta$ angle of $25.43^{\circ}$. The two main peaks of $\mathrm{CaSO}_{4} \cdot 2 \mathrm{H}_{2} \mathrm{O}$ (gypsum) corresponding to the (020) and (021) planes appear at $11.58^{\circ}$ and $20.72^{\circ}$ respectively. It can be observed that intensity of these peaks changes as the PVC particles content does. From Figure 6, following the peak intensity ratio between $(100)_{\text {anh }} /(020)_{\text {gyp }}$, it was observed that $(100)$ intensity of $\mathrm{CaSO}_{4}$ decrease and the (020) intensity of $\mathrm{CaSO}_{4} \cdot 2 \mathrm{H}_{2} \mathrm{O}$ increase as the PVC increase, indicating that reaction 1 was proceeding faster until a limiting value of approximately $20 \mathrm{wt} \%$ of PVC was reached. Consequently, experimental evidence indicates that PVC has some catalytic effect on the hydration reaction, but it has a deleterious 


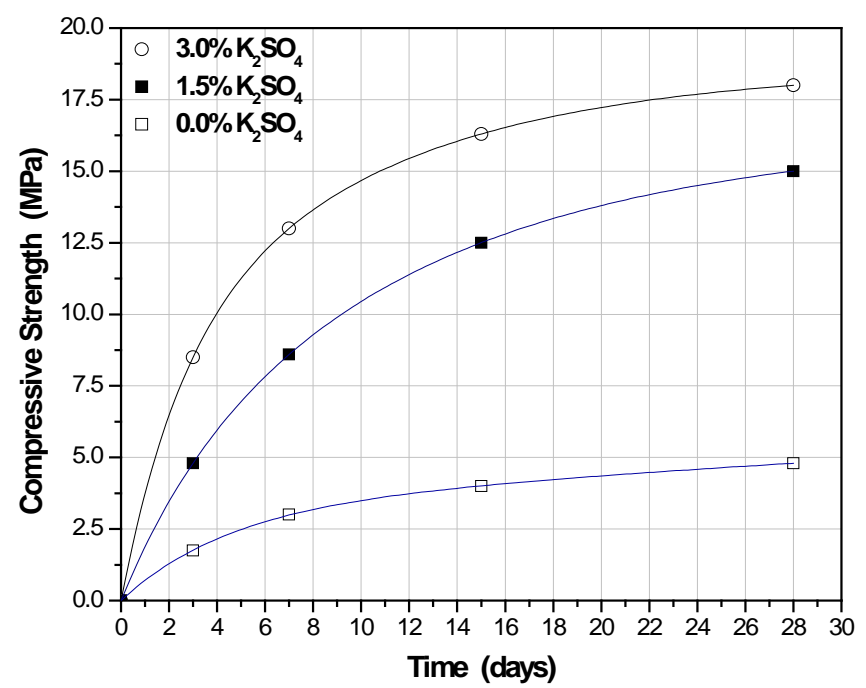

Figure 5. Compressive strength of anhydrite with $0.3 \mathrm{wt} \% \mathrm{Ca}(\mathrm{OH})_{2}$ and using different amounts of $\mathrm{K}_{2} \mathrm{SO}_{4}$ catalyst. All samples made using water/fluorgypsum of 0.35 and cured at $25^{\circ} \mathrm{C}$.

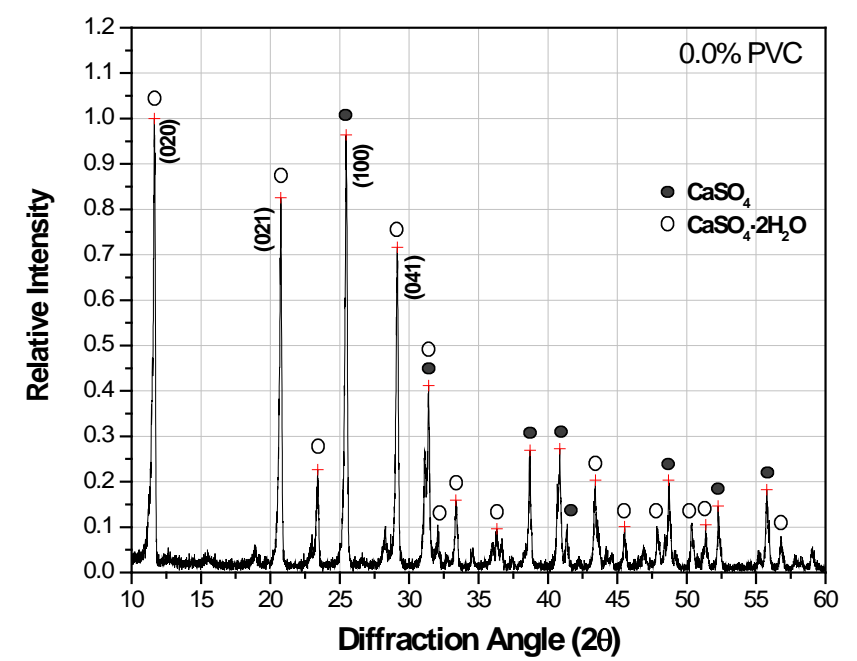

(a)

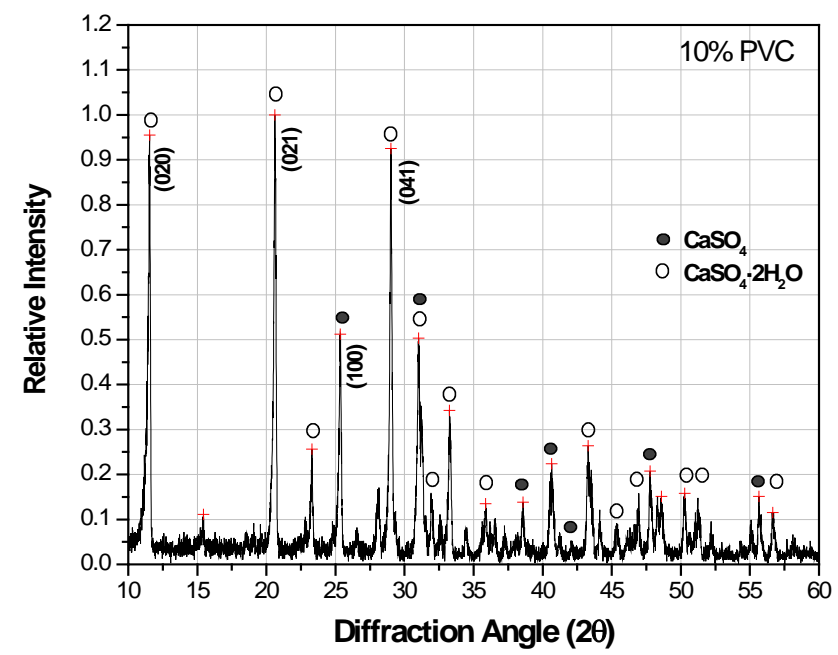

(b) 


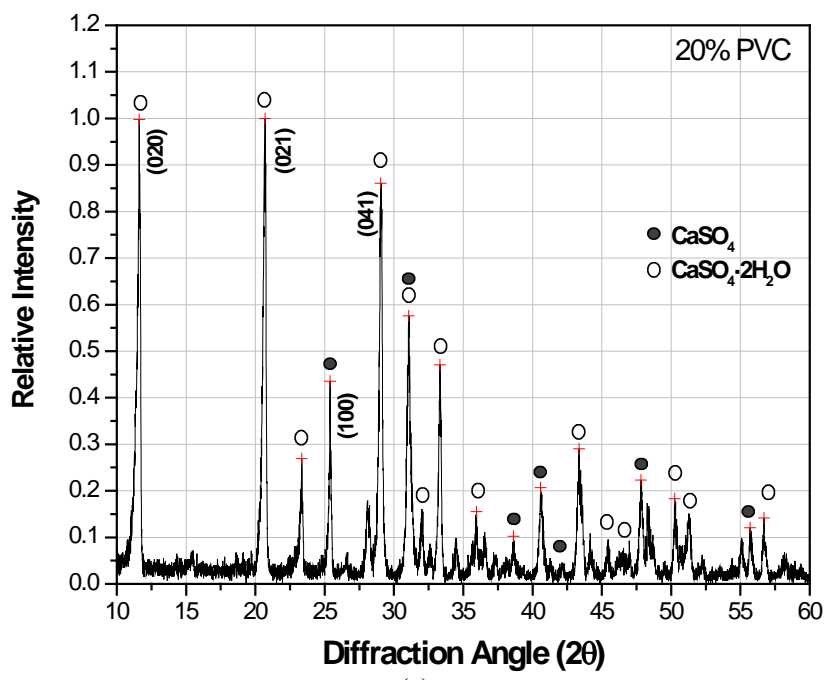

(c)

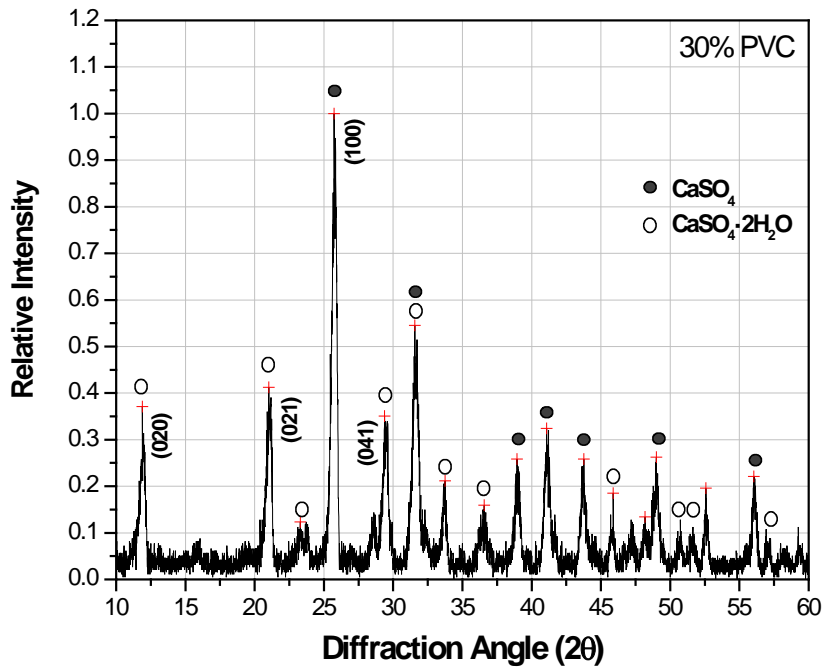

(d)

Figure 6. XRD patterns of fluorgypsum after 3 days with different concentrations of PVC particles. (a) $0.0 \mathrm{wt} \%$; (b) $10 \mathrm{wt} \%$; (c) $20 \mathrm{wt} \%$; (d) $30 \mathrm{wt} \%$.

effect on hydration if added in excess as shown in Figure 6(d), where the amount of $\mathrm{CaSO}_{4} \cdot 2 \mathrm{H}_{2} \mathrm{O}$ was the lowest value at $30 \mathrm{wt} \%$ of PVC particles. Therefore, there is probably some kind of chemical interaction between calcium sulfate and PVC particles.

From $\mathrm{x}$-ray diffraction patterns obtained at different curing times varying the concentration of PVC particles as those shown in Figure 6, it was possible to estimate the amount of gypsum $\left(\mathrm{CaSO}_{4} \cdot 2 \mathrm{H}_{2} \mathrm{O}\right)$ formed during the hydration process. Quantitative analysis by diffraction is based on the fact that the intensity of the diffraction pattern of a particular phase in a mixture of phases depends on the concentration of that phase in the mixture. The relationship between intensity and concentration is not generally linear, because diffracted intensity depends on the absorption coefficient of the mixture. Nevertheless, the concentration can be approximately calculated by means of a set of standard specimens and constructing a calibration curve [22]. Figure 7 represents the relationship between gypsum produced with different PVC additions at different times. According to these results, PVC particles increase the amount of $\mathrm{CaSO}_{4} \cdot 2 \mathrm{H}_{2} \mathrm{O}$ produced during the hydration process of $\mathrm{CaSO}_{4}$. Nevertheless, adding PVC particles above $20 \mathrm{wt} \%$ seems to retard the kinetics of anhydrite hydration. In general, PVC pipes formulation incorporate together with the polymer other compounds like calcium carbonate $\left(\mathrm{CaCO}_{3}\right)$, titanium oxide $\left(\mathrm{TiO}_{2}\right)$, calcium stearate $\left(\mathrm{Ca}\left(\mathrm{C}_{17} \mathrm{H}_{35} \mathrm{COO}\right)_{2}\right)$ and small amounts of other additives used as stabilizers to 


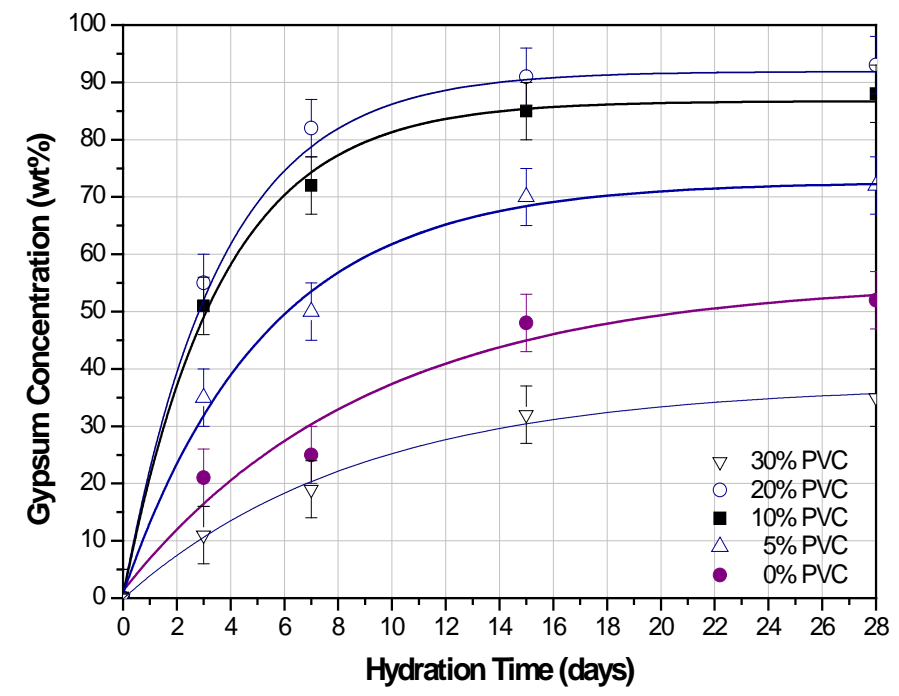

Figure 7. Experimental relationship between $\mathrm{CaSO}_{4} \cdot 2 \mathrm{H}_{2} \mathrm{O}$ (gypsum) formation and curing time in fluorgypsum composites formulated with different concentration of PVC particles.

improve the performance of the final product [23]. Probably at high concentrations one of these chemical compounds could be interacting with the CaSO4 leading to the retarding effect observed in fluorgypsum hydration.

The average compressive strength values reported on Figure 8(a) were obtained from 5 samples made of each composition and tested in exactly the same conditions. SEM images from flat surfaces of fluorgypsum and $20 \mathrm{wt} \%$ PVC/fluorgypsum after 3 days are also shown in Figure 8. In all cases and according to these results, the highest compressive strength could be located at a PVC content between $10 \mathrm{wt} \%$ to $20 \mathrm{wt} \%$. From the strength development process, one can see that the final strength of the fluorgypsum-PVC composites probably is related to the catalytic effect on density of gypsum crystals, suggested by the SEM pictures at high magnification shown in Figures 8(b) and (c). According to these images, PVC particles probably promote the density of gypsum needles, increasing in some extent crystal bonding in the solid.

Gypsum does not behave like a compact solid due to its high void fraction. The change of mechanical strength in solids as a function of porosity has been estimated by the several exponential-type relationships [24]-[26], always porosity leading to lower strength values. Concerning gypsum plaster solids, the attained experimental compressive value experimentally reported fluctuates between approximately 15 to $20 \mathrm{MPa}$ with porosity content of $2 \%$ to $45 \%$ [27]. Besides, experimental results have found that the addition of only $1 \%$ of deflocculating additives to calcium sulfate casts can lead to compressive strengths higher than $34 \mathrm{MPa}$ [28]. From the SEM images shown in Figure 8, the porosity of the fluorgypsum composites can be estimated to be between $20 \%$ to $25 \%$. From the compressive value of 36 MPa reached in the fluorgypsum-PVC composites here produced, because they present the same porosity as those reported elsewhere, the enhanced compressive value obtained suggests that PVC particles are reinforcing the gypsum matrix. Rigid PVC compounds generally used to produced pipes, present a yield strength that fluctuates between 40 to $60 \mathrm{MPa}$ [23]. Then, the observed compressive increase could be assign to the reinforcement of the matrix by the presence of PVC particles, together with the catalytic effect of the PVC scrap that modifies the density of the gypsum crystals and the number of bonds between them.

Nevertheless, more experimental work has to be carried out in this direction to study and completely appreciate the effect of PVC particle size, porosity and void size distribution on the final mechanical behavior of fluorgypsum-PVC composites. Because almost all hydraulic binders use small amounts of Portland cement and water-soluble polymers to even further improve mechanical properties and stability, therefore, there is a promising prospective to produce environmental friendly gypsum composites with compressive strengths well above the $36 \mathrm{MPa}$ reported in the present work.

\section{Conclusions}

The dependence of the hydration process and the compressive strength for fluorgypsum-PVC particles composites 


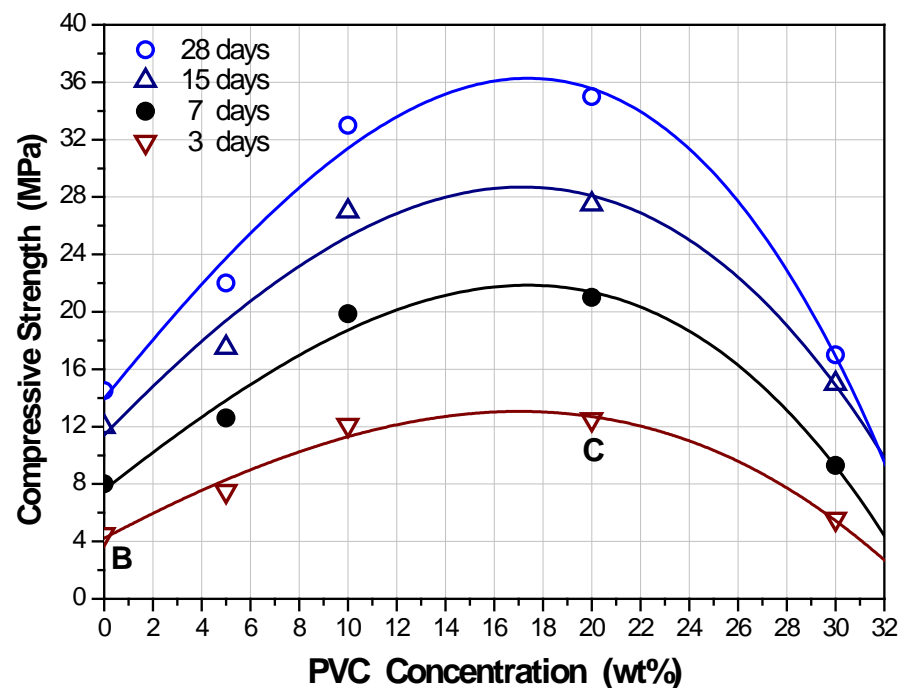

(a)
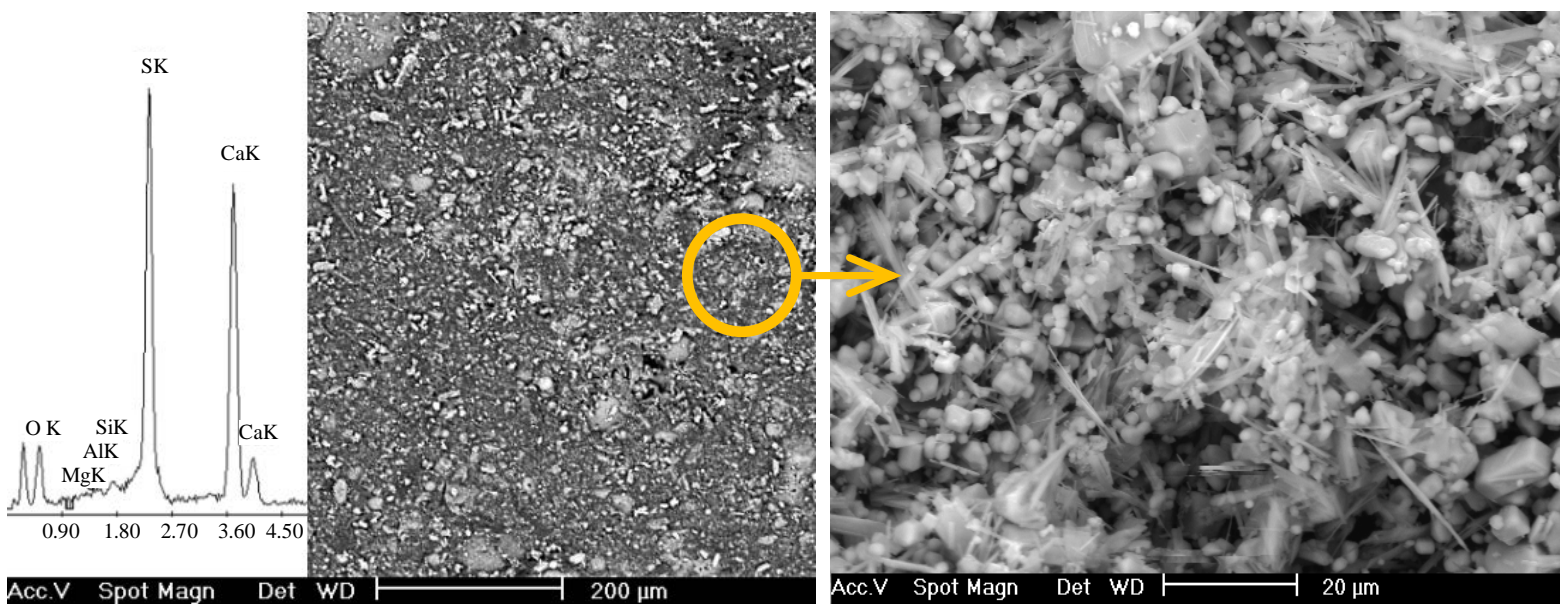

(b)
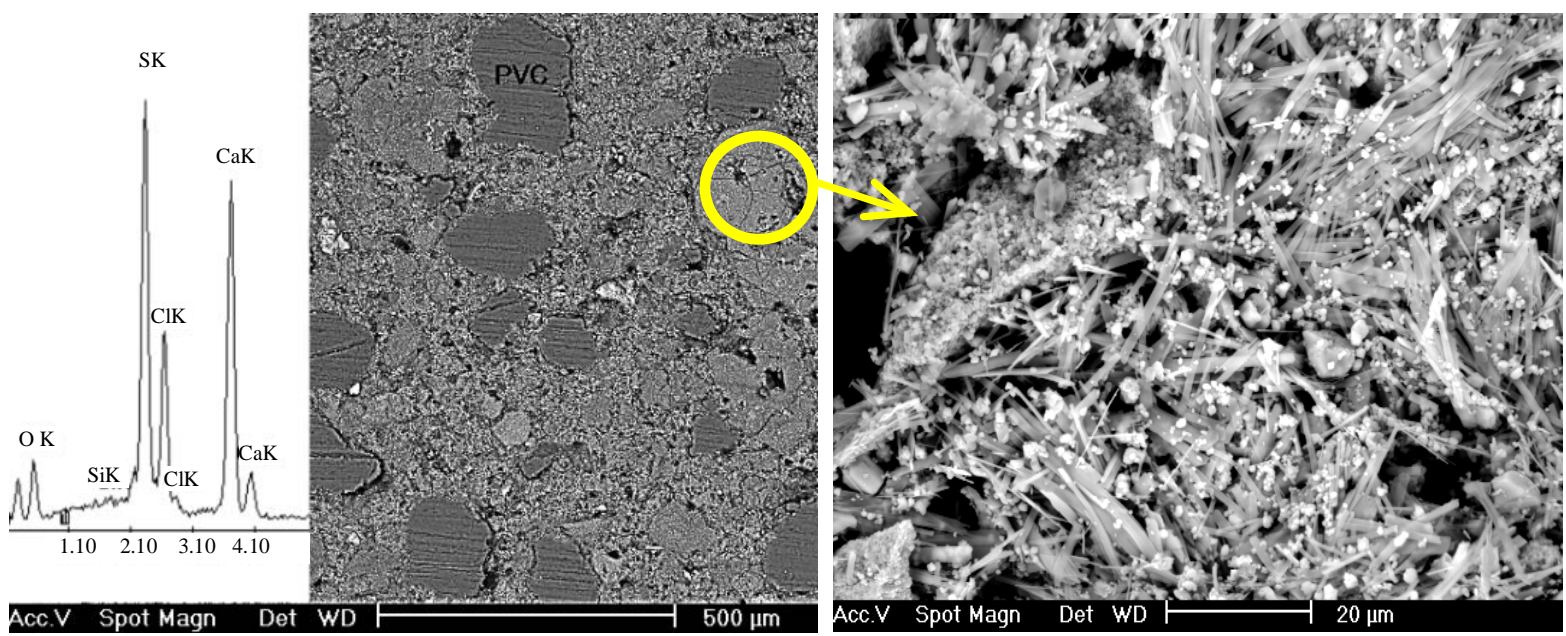

(c)

Figure 8. (a) Compressive strength of fluorgypsum/PVC composites after different curing times; (b) Microstructure and chemical analysis at low (left) and high magnification (rigth) of sample labeled with B on graph a; (c) Microstructure and chemical analysis at low (left) and high magnification (rigth) of sample labeled with $\mathrm{C}$ on graph a. 
were analyzed experimentally in this preliminary work. The following conclusions can be drawn:

- PVC particles enhance the hydration process of anhydrite $\left(\mathrm{CaSO}_{4}\right)$ so the composite sets rapidly attaining a compressive strength of $8 \mathrm{MPa}$ after 1 day.

- The strength of the material increases continuously reaching $36 \mathrm{MPa}$ after 28 days probably due to the combined effect of PVC particles as reinforcement and catalyst.

- Adding more than $20 \mathrm{wt} \%$ of PVC particles have a deleterious effect on anhydrite hydration, retarding the formation of gypsum $\left(\mathrm{CaSO}_{4} \cdot 2 \mathrm{H}_{2} \mathrm{O}\right)$.

- There is the possibility of reusing PVC scrap and fluorgypsum to produce a low cost composite binder that could be employed in block making and floor leveling.

\section{References}

[1] Sadat-Shojai, M. and Bakhshandeh, G.R. (2011) Recycling of PVC Wastes. Polymer Degradation and Stability, 96, 404-415. http://dx.doi.org/10.1016/j.polymdegradstab.2010.12.001

[2] Yarahmadi, N., Jakubowicz, I. and Martinsson, L. (2003) PVC Floorings as Post Consumer Products for Mechanical Recycling and Energy Recovery. Polymer Degradation and Stability, 79, 439-448. http://dx.doi.org/10.1016/S0141-3910(02)00360-9

[3] Al-Salem, S.M., Lettieri, P. and Baeyens, J. (2009) Recycling and Recovery Routes of Plastic Solid Waste: A Review. Waste Management, 29, 2625-2643. http://dx.doi.org/10.1016/j.wasman.2009.06.004

[4] Garcia, D., Balart, R. and Parres, F. (2007) Characterization of Blends of Poly(vinyl chloride) Waste for Building Applications. Journal of Material Science, 42, 10143-10151. http://dx.doi.org/10.1007/s10853-007-2067-y

[5] Martinez-Aguilar, O.A., Castro-Borges, P. and Escalante-García, J.I. (2010) Hydraulic Binders of Fluorogypsum-Portland Cement and Blast Furnace Slag, Stability and Mechanical Properties. Construction and Building Materials, 24, 631-639. http://dx.doi.org/10.1016/j.conbuildmat.2009.11.006

[6] Garg, M., Jain, N. and Singh, M. (2009) Development of Alpha Plaster from Phosphogypsum for Cementitious Binders. Construction and Building Materials, 23, 3138-3143. http://dx.doi.org/10.1016/j.conbuildmat.2009.06.024

[7] Fauziah, I., Zauyah, S. and Jamal, T. (1996) Characterization and Land Application of Red Gypsum: A Waste Product from the Titanium Dioxide Industry. Science of the Total Environment, 188, 243-251. http://dx.doi.org/10.1016/0048-9697(96)05179-0

[8] Prakaypun, W. and Jinawath, S. (2003) Comparative Effect of Additives on the Mechanical Properties of Plasters Made from Flue-Gas Desulfurized and Natural Gypsums. Materials and Structures, 36, 51-58. http://dx.doi.org/10.1007/BF02481571

[9] Bediako, M. and Frimpong, A.O. (2013) Alternative Binders for Increased Sustainable Construction in Ghana-A Guide for Building Professionals. Materials Science and Applications, 4, 20-28. http://dx.doi.org/10.4236/msa.2013.412A004

[10] Colak, A. (2000) Density and Strength Characteristics of Foamed Gypsum. Cement and Concrete Composites, 22, 193-200. http://dx.doi.org/10.1016/S0958-9465(00)00008-1

[11] Gutiérrez-González, S., Gadea, J., Rodríguez, A., Blanco-Varela, M.T. and Calderón, V. (2012) Compatibility between Gypsum and Polyamide Powder Waste to Produce Lightweight Plaster with Enhanced Thermal Properties. Construction and Building Materials, 34, 179-185. http://dx.doi.org/10.1016/j.conbuildmat.2012.02.061

[12] Herrero, S., Mayor, P. and Hernandez-Olivares, F. (2013) Influence of Proportion and Particle Size Gradation of Rubber from End-of-Life Tires on Mechanical, Thermal and Acoustic Properties of Plaster-Rubber Mortars. Materials and Design, 47, 633-642. http://dx.doi.org/10.1016/j.matdes.2012.12.063

[13] Santos, A.G. (2009) PPF-Reinforced ESP-Lightened Gypsum Plaster. Materiales de Construcción, 59, 105-124.

[14] Shi, T., Sun, W. and Yang, Y. (2014) Preparation and Heat Storage/Release Behavior of Latent Heat Storage GypsumBased Building Materials. Materials and Structures, 47, 533-539.

[15] Yan, P. and You, Y. (1998) Studies on the Binder of Fly Ash-Fluorogypsum-Cement. Cement and Concrete Research, 28, 135-140. http://dx.doi.org/10.1016/S0008-8846(97)00247-0

[16] O’Rourke, O., McNally, C. and Richardson, M.G. (2009) Development of Calcium Sulfate-ggbs-Portland Cement Binders. Construction and Building Materials, 23, 340-346. http://dx.doi.org/10.1016/j.conbuildmat.2007.11.016

[17] Kovler, K. (1998) Setting and Hardening of Gypsum-Portland Cement-Silica Fume Blends, Part 2: Early Strength, DTA, XRD and SEM Observations. Cement and Concrete Research, 28, 523-531. http://dx.doi.org/10.1016/S0008-8846(98)00004-0

[18] Odler, I. (2000) Special Inorganic Cements. F \& FN SPON, London. 
[19] Welch, F.C. (1923) Effects of Accelerators and Retarders on Calcined Gypsum. Journal of the American Ceramic Society, 6, 1197-1207. http://dx.doi.org/10.1111/j.1151-2916.1923.tb17689.x

[20] Sievert, T., Wolter, A. and Singh, N.B. (2005) Hydration of Anhydrite of Gypsum $\mathrm{CaSO}_{4}$ (II) in a Ball Mill. Cement and Concrete Research, 35, 623-630. http://dx.doi.org/10.1016/j.cemconres.2004.02.010

[21] Singh, N.B. (2005) The Activation Effect of $\mathrm{K}_{2} \mathrm{SO}_{4}$ on the Hydration of Gypsum Anhydrite CaSO ${ }_{4}$ (II). Journal of the American Ceramic Society, 88, 196-201. http://dx.doi.org/10.1111/j.1551-2916.2004.00020.x

[22] Cullity, B.D. and Stock, S.R. (2001) Elements of X-Ray Diffraction. Prentice Hall, Saddle River.

[23] Wilkes, C.E., Summers, J.W. and Daniels, C.A. (2005) PVC Handbook. Hanser-Verlag, Berlin.

[24] Schiller, K.K. (1960) Skeleton Strength and Critical Porosity in Set Sulphate Plasters. British Journal of Applied Physics, 11, 338-342. http://dx.doi.org/10.1088/0508-3443/11/8/307

[25] Ryshkevitch, R. (1953) Compression Strength of Porous Sintered Alumina and Zirconia. Journal of the American Ceramic Society, 36, 65-68. http://dx.doi.org/10.1111/j.1151-2916.1953.tb12837.x

[26] Hasselman, D.P.H. (1969) Griffith Flaws and the Effect of Porosity on Tensile Strength of Brittle Ceramics. Journal of the American Ceramic Society, 52, 457-462. http://dx.doi.org/10.1111/j.1151-2916.1969.tb11982.x

[27] Colak, A. (2006) Physical and Mechanical Properties of Polymer-Plaster Composites. Materials Letters, 60, $1977-1982$. http://dx.doi.org/10.1016/j.matlet.2005.12.062

[28] Bijen, J. and Plas, C. (1992) Polymer Modified Glass Fiber Reinforced Gypsum. Materials and Structure, 25, $107-114$. http://dx.doi.org/10.1007/BF02472464 